\title{
ARRDC3 Gene
}

National Cancer Institute

\section{Source}

National Cancer Institute. ARRDC3 Gene. NCI Thesaurus. Code C117150.

This gene plays a role in the positive regulation of receptor signaling. 